\title{
PUPUK CAIR DARI RUMPUT LAUT Eucheuma cottonii, Sargassum sp. DAN Gracilaria sp. MENGGUNAKAN PROSES PENGOMPOSAN
}

\section{Liquid Fertilizer from Eucheuma cottonii, Sargassum sp. and Gracilaria sp. using Composting Process}

\author{
Bakti Berlyanto Sedayu ${ }^{1 *}$, I Made Susi Erawan' ${ }^{1}$, dan Luthfi Assadad \\ ${ }^{1}$ Loka Penelitian dan Pengembangan Mekanisasi Pengolahan Hasil Perikanan, \\ JI. Imogiri Barat Km11,5. Bantul - DI.Yogyakarta, Indonesia \\ * Korespondensi Penulis: bakti@kkp.go.id
}

Diterima: 8 Januari 2014; Disetujui: 28 Mei 2014

\begin{abstract}
ABSTRAK
Pembuatan pupuk organik cair berbahan dasar rumput laut untuk mendapatkan pupuk yang kaya kandungan hormon pemacu tumbuh (HPT) telah dilakukan dengan teknik pengomposan. Tiga jenis rumput laut segar yaitu: Eucheuma cottonii, Sargassum sp. dan Gracilaria sp. dikompos (semi-anaerob) selama 30 hari menggunakan drum komposter, dengan ditambahkan bakteri starter komersial dan ikan rucah untuk mempercepat proses penguraian serta menambah unsur hara pupuk cair yang dihasilkan. Pupuk cair (lindi) yang dihasilkan kemudian dianalisis senyawa HPT-nya, meliputi: auksin, giberelin dan sitokinin, serta unsur hara makro dan mikronya. Selanjutnya, pupuk cair diujicobakan terhadap tanaman terung (Solanum melongena) dan tomat (Lycopercisum esculentum). Pupuk organik cair (lindi) hasil proses pengomposan terbukti mengandung senyawa HPT yang tinggi, yaitu: auksin (144-1128 ppm), giberelin (130-1552 $\mathrm{ppm})$, dan sitokinin yang terdiri dari kinetin (58-65 ppm) dan zeatin (65-86 ppm). Sedangkan masing-masing kandungan tertinggi dari senyawa tersebut berturut-turut didapatkan dari rumput laut yang berasal dari E.cottonii, Gracilaria sp. dan Sargassum sp. Jumlah kandungan HPT tersebut lebih tinggi dibandingkan dengan jumlah yang terkandung dalam pupuk cair rumput laut komersial, namun unsur hara makro dan mikro yang terkandung masih lebih rendah dari standar pupuk cair organik yang dipersyaratkan. Ujicoba pupuk cair terhadap tanaman terung dan tomat menunjukkan pertumbuhan tanaman yang lebih cepat dibandingkan kontrol.
\end{abstract}

KATA KUNCl: hormon pemacu tumbuh, pupuk organik cair, pengomposan, rumput laut

\section{ABSTRACT}

Effort to obtain organic liquid fertilizers seaweed containing high growth promoting hormones (GPH) has been carried out using composting technique. Fresh seaweeds, Eucheuma cottonii, Sargassum sp., and Gracilaria sp. were composted in semi-anaerobic condition for 30 days in compost drum. A comercial bioactivator and minced trash fish were added in order to boost the fermentation process as well as to improve the nutrient elements of the fertilizers. The organic liquid fertilizers produced were then analysed for their GPH contents, and their macro and micro nutrients. Afterwards, the fertilizers were tested to the eggplant (Solanum melongena) and tomato (Lycopercisum esculentum) plants. The results showed that the liquid fertilizers contained high amount of GPH, i.e. auxin (144-1128 ppm), giberelin (130-1552 ppm), and cytokinin which was consist of kinetin (58-65 ppm) and zeatin (65-86 ppm), while the highest amount of those GPHs were belong to E.cottonii, Gracilaria sp. and Sargassum sp., respectively. The amount of GPH were considered to be higher than those of the commercial liquid seaweed fertilizer. Nevertheless, the amounts of macro and micro nutrients in the liquid fertilizer were still below the standard of organic liquid fertilizer. In addition, the liquid fertilizer demonstrated to boost the growth of the eggplant and tomato plants in compare with the control.

KEYWORDS: composting, growth promoting hormones, organic liquid fertilizer, seaweed 


\section{PENDAHULUAN}

Indonesia merupakan salah satu produsen rumput laut yang terbesar di dunia, namun demikian, pemanfaatan rumput laut di dalam negeri hingga saat ini masih terbatas sebagai produk pangan, produk semi-jadi, serta beberapa produk kosmetik, sedangkan penggunaan rumput laut untuk bidang pertanian dan hortikultura masih belum banyak dilakukan. Di negara-negara lain di dunia, aplikasi rumput laut untuk tanaman pertanian telah lama dilakukan, seperti berbagai jenis atau bentuk preparasi rumput laut diantaranya liquid seaweed fertilizer (LSF), seaweed liquid fertilizer (SLF), liquid fertilizer (LF), dan chopped powdered algal manure yang umum beredar di pasaran (Sedayu et al., 2013). Sedangkan di Indonesia, rumput laut cokelat jenis Sargassum $\mathrm{sp}$. kini juga mulai banyak dicari oleh industri pengolahan pupuk organik, salah satunya oleh perusahaan pupuk Cina.

Penggunaan jenis pupuk organik akhir-akhir ini terus meningkat disebabkan oleh dampak negatif terhadap ekosistem pertanian yang timbul akibat meningkatnya intensitas pemakaian pupuk kimia dari waktu ke waktu. Pupuk kimia relatif lebih mudah didapatkan di pasaran namun demikian harganya relatif mahal (Dewanto et al., 2013) dan kurang ramah lingkungan. Penggunaan pupuk kimia terbukti telah menimbulkan masalah serius, antara lain pencemaran tanah dan air, penurunan tingkat kesuburan tanah, dan ketergantungan petani secara ekonomi dan sosial (Udiyani \& Setiawan, 2003). Selain itu, penggunaan pupuk kimia juga memiliki dampak berbahaya terhadap kesehatan manusia (Camargo \& Alonso, 2006). Pemberian pupuk organik mampu memperbaiki sifat-sifat tanah seperti sifat fisik, kimia dan biologi. Bahan organik merupakan perekat butiran lepas, sumber hara tanaman, dan sumber energi dari sebagian besar organisme tanah. Selain itu penggunaan pupuk organik juga dinilai mampu mengurangi aplikasi pupuk anorganik yang berlebihan (Amilia, 2011).

Rumput laut sesungguhnya telah lama digunakan secara langsung sebagai kondisioner tanah maupun pupuk di berbagai wilayah pesisir di dunia (Haslam \& Hopkins, 1996; Cocozza et al., 2011), dan ekstrak rumput laut juga telah banyak dipasarkan sebagai bahan tambahan pada pupuk tanaman yang manfaat serta keuntungan penggunaannya telah banyak dilaporkan (Fornes et al., 2002; Padhi \& Swain, 2006; Sivansankari et al., 2006; Prithiviraj, 2009; Sedayu et al., 2013). Selain banyak mengandung mineral-mineral penting dari laut yang dibutuhkan oleh tanaman, rumput laut juga memiliki kandungan hormon pemacu tumbuh yang telah terbukti mampu meningkatkan pertumbuhan tanaman maupun hasil panen (Fornes et al., 2002; Padhi \& Swain, 2006; Sivansankari et al., 2006; Prithiviraj, 2009). Tidak seperti halnya pupuk kimia, ekstrak yang terbuat dari rumput laut dapat terdegradasi secara alami, tidak beracun, tidak mengkontaminasi, dan aman terhadap manusia dan hewan (Dhargalkar \& Pereira, 2005). Pemanfaatan rumput laut sebagai pupuk atau bahan tambahan pupuk diharapkan dapat menjadi alternatif pemecahan permasalahan lingkungan karena aman bagi mikroba tanah maupun tanaman dan juga meningkatkan nilai ekonomi rumput laut di Indonesia.

Beberapa metode pembuatan pupuk cair rumput laut telah dilakukan sebelumnya, diantaranya adalah ekstraksi cairan rumput laut segar secara fisik, maupun ekstraksi dengan mengunakan alkali (Basmal, 2010; Sedayu et al., 2013). Dengan metode tersebut, kandungan senyawa HPT dan unsur hara pupuk cair yang didapatkan masih belum optimal. Pada penelitian ini pembuatan pupuk cair rumput laut dari beberapa jenis rumput laut dilakukan dengan cara pengomposan untuk mendapatkan pupuk cair yang memiliki kandungan HPT yang tinggi.

\section{BAHAN DAN METODE}

Rumput laut segar, Eucheuma cottonii, Sargassum sp. dan Gracilaria sp., yang diperoleh dari perairan Jepara-Jawa Tengah dibawa ke laboratorium tempat pengolahan pupuk dengan menggunakan karung goni (transportasi kering), dengan waktu tempuh \pm 4 jam. Rumput laut kemudian dicuci bersih menggunakan air tanah untuk menghilangkan lumpur, pasir, garam, cangkang kerang, serta kotoran yang menempel pada talus. Setelah dicuci, rumput laut dicacah secara manual dengan ukuran $\pm 5 \mathrm{~cm}$ lalu digiling hingga lumat, kecuali untuk Sargassum sp. hanya dicacah saja,kemudian masing-masing rumput laut dimasukkan kedalam drum komposter yang terbuat dari bahan plastik (Gambar 1). Untuk mempercepat proses penguraian digunakan starter bakteri komersial, EM4 dari PT. Songgolangit Persada, yang mengandung bakteri fermentasi Lactobacillus, Actinomycetes, jenis jamur fermentasi, serta kandungan lainnya. Bakteri komersial EM4 yang telah diencerkan dalam air menjadi $2 \%$ larutan, disemprotkan ke masing-masing rumput laut sambil diaduk hingga merata ke seluruh permukaan $( \pm 200$ $\mathrm{ml}$ larutan untuk $10 \mathrm{~kg}$ rumput laut). Selain itu, ditambahkan juga ikan rucah yang telah digiling, terdiri dari campuran ikan kurisi (Nemitarus nematophorus) dan kuniran (Upeneus sulphureus), dengan perbandingan rumput laut:ikan rucah adalah 5:1 (w/ w). Hancuran ikan rucah digunakan sebagai media nutrisi untuk penguraian dan sekaligus untuk 


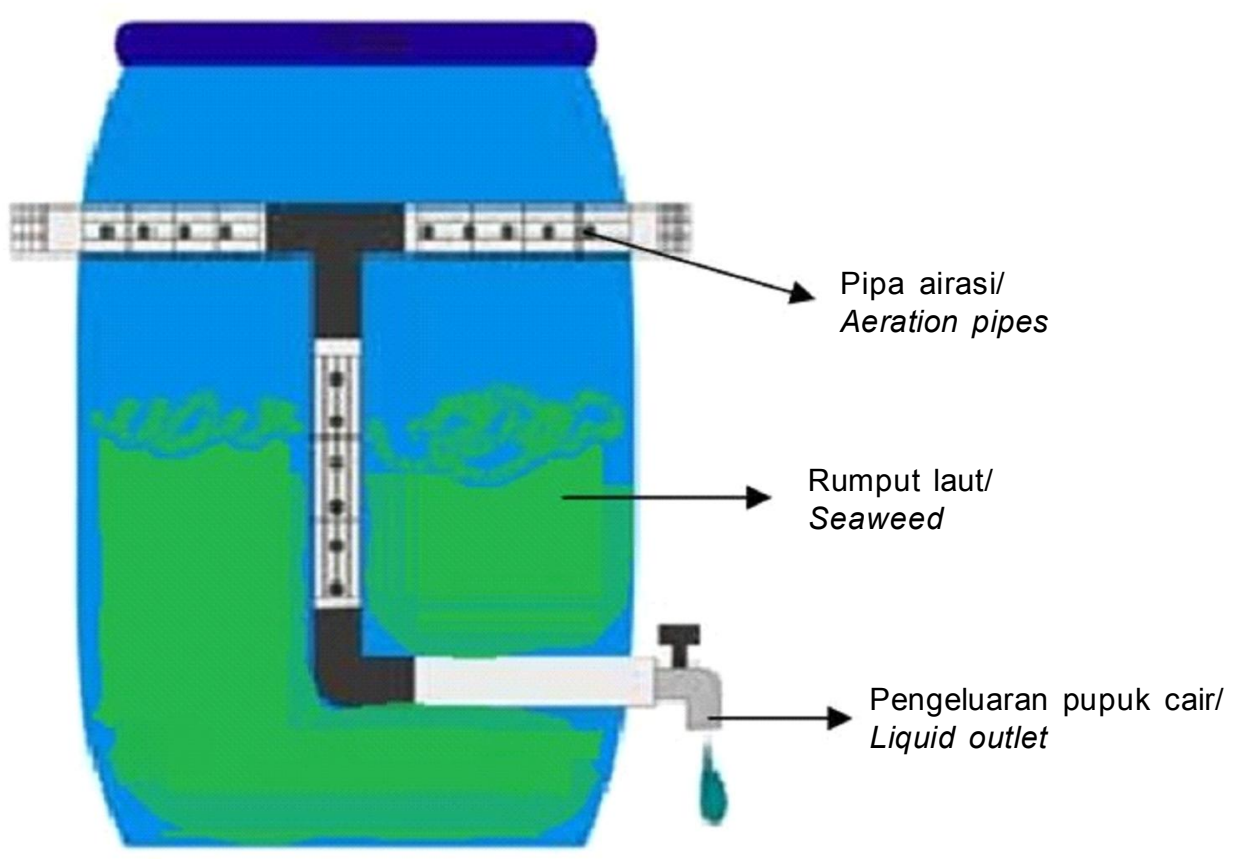

Gambar 1. llustrasi pengomposan rumput laut dengan drum komposter. Figure 1. Illustration of seaweed composting in composting drum.

meningkatkan kandungan hara pupuk yang dihasilkan. Jumlah seluruh bahan-bahan yang dimasukkan $\pm 3 / 4$ volume drum komposter.

Selanjutnya komposter ditutup rapat, Ialu didiamkan selama 30 hari sampai menghasilkan pupuk organik cair (lindi). Proses pengomposan dilakukan dalam kondisi semi-anaerob oleh pipa aerasi yang terdapat dalam drum komposter. Pupuk cair yang dihasilkan kemudian dikeluarkan melalui keran pengeluaran ditampung untuk dianalisis dan diujicobakan ke tanaman. Analisis pupuk cair yang dilakukan meliputi hormon pemacu tumbuh, yaitu:auksin, sitokinin, dan giberelin, serta unsur hara makro maupun mikro.

Preparasi dan analisis HPT pupuk organik cair dilakukan dengan modifikasi metode Linskens dan Jackson (1987) menggunakan HPLC Waters 2487 dan detektor UV-Vis (Sedayu et al., 2013). Hasil kuantitatif HPT dihitung berdasarkan perbandingan luas area grafik senyawa HPT dengan standartnya. Pupuk organik cair rumput laut yang dihasilkan kemudian diujicobakan terhadap tanaman terung (Solanum melongena) dan tomat (Lycopercisum esculentum) untuk mengetahui pengaruhnya terhadap pertumbuhan tanaman. Masing-masing benih tanaman disemai dan ditanam dalam plastik polybag di tempat yang terlindung dari terik matahari langsung dan hama tanaman. Penyemprotan dengan larutan pupuk cair dilakukan setiap tiga hari sekali, dengan perbandingan pupuk cair dengan air yaitu 1: 200. Pengamatan yang dilakukan meliputi: tinggi tanaman, diameter batang, panjang dan lebar daun, serta jumlah daun, dengan 5 kali ulangan sampel.

\section{HASIL DAN PEMBAHASAN}

\section{Kandungan Hormon Pemacu Tumbuh}

Pupuk organik berbahan dasar rumput laut memiliki keunggulan dibandingkan pupuk organik lainnya yaitu dalam hal kandungan hormon pemacu tumbuhnya yang tinggi. Hormon ini ditujukan untuk merangsang pertumbuhan pada tanaman sehingga tanaman dapat tumbuh, berbuah atau berbunga lebih cepat, lebih banyak atau lebih besar. Kandungan HPT dalam pupuk organik cair masing-masing rumput laut yang dihasilkan dapat dilihat pada Tabel 1.

Kandungan hormon auksin pupuk organik cair yang dihasilkan dari ketiga jenis rumput laut hasil pengomposan memiliki nilai yang lebih tinggi dibandingkan dengan pupuk organik komersial, D.I Grow (PT. Diamond Interest International), dengan kandungan tertinggi didapatkan dari pupuk cair rumput laut E.cottonii, yaitu sebesar 1128 ppm. Demikian pula 
Tabel 1. Kandungan HPT pada pupuk organik cair rumput laut dengan teknik pengomposan.

Table 1. Growth promoting hormones contained in composted liquid seaweed fertilizer.

\begin{tabular}{lcccc}
\hline $\begin{array}{c}\text { Hormon Pemacu Tumbuh/ } \\
\text { Growth Promoting } \\
\text { Hormones }\end{array}$ & E. cottonii & $\begin{array}{c}\text { Sargassum } \\
\text { sp. }\end{array}$ & $\begin{array}{c}\text { Gracilaria } \\
\text { sp. }\end{array}$ & $\begin{array}{c}\text { Pupuk Organik Rumput Laut } \\
\text { Komersial/Commercial } \\
\text { Seaweed Organic Liquid } \\
\text { Fertilizer }\end{array}$ \\
\hline Auksin/Auxin (IAA) (ppm) & $1.128 \pm 199$ & $148 \pm 33$ & $144 \pm 26$ & 130 \\
\hline Giberelin/Giberelin (ppm) & $130 \pm 3$ & $160 \pm 15$ & $1.552 \pm 106$ & 122 \\
\hline $\begin{array}{l}\text { Sitokinin/Cytokinin } \\
\text { - Kinetin (ppm) }\end{array}$ & $58 \pm 18$ & $71 \pm 4$ & $65 \pm 3$ & 61 \\
- Zeatin (ppm) & $65 \pm 10$ & $86 \pm 10$ & $81 \pm 3$ & 67 \\
\hline
\end{tabular}

halnya dengan kandungan hormon giberelin, ketiga pupuk cair yang dihasilkan mengandung giberelin yang lebih tinggi dibandingkan pupuk komersial, dengan pupuk cair Gracilaria sp. yang memiliki giberelin tertinggi. Kandungan hormon sitokinin, yang terdiri atas kinetin dan zeatin, secara umum hampir sama dengan pupuk cair rumput laut komersial.

Masing-masing jenis rumput laut memiliki kandungan unsur senyawa kimia berbeda, yang menyebabkan kandungan HPT dari tiap-tiap pupuk cair yang dihasilkan juga berbeda. Han (2006) mengidentifikasi adanya kandungan auksin dari 16 jenis spesies alga laut yang ada di perairan China. Hasilnya didapatkan bahwa senyawa auksin terdapat pada seluruh alga laut yang diamatinya dengan distribusi konsentrasi yang besar yaitu 0,001-0,11 ppm berat basah. Konsentrasi auksin terendah ditemukan pada alga coklat sedangkan yang tertinggi pada alga merah. Selain itu, perbedaan kandungan HPT pada rumput laut juga dipengaruhi oleh beberapa faktor, diantaranya oleh faktor musim dan fase perkembangan rumput laut (Mooney \& van Staden, 1984).

Selain itu, dibandingkan dengan pupuk cair rumput laut jenis E.cottonii dari hasil penelitian Sedayu et al. (2013), yang menggunakan teknik ekstraksi fisik dengan cara menghancurkan rumput laut lalu menyaring ekstrak cairnya, maka kandungan HPT yang didapatkan dengan cara pengomposan, secara umum, juga memiliki nilai yang lebih tinggi. Masingmasing hormon pemacu tumbuh memiliki fungsi yang berbeda, senyawa auksin berperan dalam proses fisiologi tumbuhan, seperti pertumbuhan, pembelahan dan diferensiasi sel, serta sintesa protein; giberelin diketahui mempengaruhi dormansi puncak, pertumbuhan kambium, geotropisme, absisi dan partenokarpi, efektif meningkatkan set buah, perangsangan pertumbuhan antar buku sehingga tumbuhan tidak kerdil (Gardner et al., 1991). Sedangkan sitokinin sangat berperan dalam pembelahan sel menghasilkan respon tumbuhan terhadap pertumbuhan tanaman, pertumbuhan buah, dan germinasi kecambah (Wu \& Lin, 2000).

\section{Kandungan Unsur Hara Makro dan Mikro}

Rumput laut mengandung komponen mineral makro, seperti kalsium, mangan dan potasium, serta mineral mikro, seperti zink, besi, cobalt, molibdate, dan boron, yang berasal dari laut (Jensen, 1993; Jimenez-Escrig \& Goni, 1999). Hasil analisis unsur hara pupuk organik cair rumput laut hasil pengomposan disajikan pada Tabel 2 .

Jumlah unsur hara makro pupuk cair rumput laut hasil pengomposan, meliputi $\mathrm{N}$-organik, $\mathrm{P}_{2} \mathrm{O}_{5}$, dan $\mathrm{K}_{2} \mathrm{O}$,memiliki nilai yang rendah. Demikian hal nya dengan kandungan unsur hara mikronya. Hal serupa juga ditemukan pada pupuk organik rumput laut Sargassum spp. yang dilaporkan oleh Win \& Saing (2008). Pupuk tersebut mengandung nilai total $\mathrm{N}$ sebesar $0,03 \%, \mathrm{P}_{2} \mathrm{O}_{5}=0,04 \%$, dan $\mathrm{K}_{2} \mathrm{O}=0,14 \%$. Demikian juga nitrogen total yang ditemukan pada rumput laut jenis Ulva sp. dan Posidonia oceanica masing-masing hanya sebesar 0,68 dan $0,80 \%$ (Han et al., 2014). Dalam proses pengomposan terjadi perubahan seperti 1) karbohidrat, selulosa, hemiselulosa, lemak dan lilin menjadi $\mathrm{CO}_{2}$ dan air, 2) protein menjadi amonia, $\mathrm{CO}_{2}$ dan air, 3) penguraian senyawa organik menjadi senyawa yang dapat diserap tanaman. Dengan perubahan tersebut, kadar karbohidrat akan hilang atau turun dan senyawa $\mathrm{N}$ yang larut (amonia) meningkat (Indriani, 2004). Namun demikian, pada penelitian ini didapatkan bahwa 
Tabel 2. Kandungan unsur hara pupuk cair rumput laut dengan metode pengomposan

Table 2. Nutrient elements contained in composted seaweed liquid fertilizer

\begin{tabular}{|c|c|c|c|c|c|}
\hline \multirow{2}{*}{ No } & \multirow{2}{*}{$\begin{array}{l}\text { Parameterl } \\
\text { Parameters }\end{array}$} & \multicolumn{3}{|c|}{ Jenis Rumput Laut/Seaweeds } & \multirow{2}{*}{$\begin{array}{l}\text { Standar Mutu*I } \\
\text { Standard quality }\end{array}$} \\
\hline & & E.cottonii & Sargassum sp. & Gracilaria sp. & \\
\hline 1 & $\mathrm{~N}$ organik $(\%)$ & 0.19 & 0.04 & 0.41 & $3-6$ \\
\hline 2 & $\mathrm{P}_{2} \mathrm{O}_{5}$ Total $(\%)$ & $7.5 \times 10^{-5}$ & $7.8 \times 10^{-5}$ & $4.5 \times 10^{-4}$ & $3-6$ \\
\hline 3 & $\mathrm{~K}_{2} \mathrm{O}$ Total $(\%)$ & $1.7 \times 10^{-6}$ & $3.2 \times 10^{-3}$ & $3.4 \times 10^{-5}$ & $3-6$ \\
\hline \multirow[t]{2}{*}{4} & Kalsium (Ca) (ppm) & 660 & 109 & 1028 & - \\
\hline & Magnesium (Mg) (ppm) & 285 & 48 & 300 & - \\
\hline 6 & Mangan (Mn) (ppm) & 0,05 & 0,3 & 10 & $250-5000$ \\
\hline 7 & Zink (Zn) (ppm) & 0,3 & 0.3 & 1 & $250-5000$ \\
\hline 8 & Besi (Fe) (ppm) & 3 & 3 & 26 & $5-50$ \\
\hline 9 & Cobalt (Co) (ppm) & $<0.01$ & 0.6 & 0.5 & $5-20$ \\
\hline 10 & Molibdate (Mo) (ppm) & $<0.02$ & $<0.2$ & $<0.2$ & $2-10$ \\
\hline 11 & Boron (B) (ppm) & 18 & $<0.01$ & 23 & $125-2500$ \\
\hline
\end{tabular}

Keterangan/Note: * Standar mutu pupuk organik cair berdasarkan Peraturan Menteri Pertanian No.70/Permentan/ SR.140/10/2011/Quality standard of organic liquid fertilizer according to The Ministry of Agriculture Regulation, Republic Indonesia, 2011.

penambahan ikan rucah belum dapat meningkatkan jumlah kandungan $\mathrm{N}$ secara signifikan, dan hal ini diduga karena belum sempurnanya proses penguraian selama 30 hari pengomposan.

Pupuk organik cair yang dihasilkan dari rumput laut Gracilaria sp. dan E.cottonii memiliki warna cokelat tua, sedangkan yang berasal dari jenis Sargassum sp. berwarna kuning kecokelatan. Nilai $\mathrm{pH}$ dari masing-masing pupuk organik cair yang dihasilkan berkisar antara 7-8, yang menunjukkan bahwa pupuk cair yang dihasilkan ideal dalam mendukung ketersediaan unsur hara tanaman. Namun demikian, ketiga pupuk cair yang dihasilkan masih memiliki bau busuk yang disebabkan karena belum selesainya proses penguraian dalam drum komposter dalam waktu 30 hari. Proses pengomposan rumput laut membutuhkan waktu yang lama, hal ini dapat disebabkan oleh tingginya nilai rasio $\mathrm{C} / \mathrm{N}$ rumput laut saat awal pengomposan. Rumput laut yang memiliki komponen utama polisakarida memiliki kandungan karbon yang tinggi, sedangkan unsur nitrogen sangat rendah. Chang dan Hsu (2008) melaporkan bahwa lama waktu pengomposan dan jumlah akumulasi $\mathrm{CO}_{2}$ dipengaruhi secara linier oleh nilai rasio $\mathrm{C} / \mathrm{N}$ awal material, dimana nilai rasio $\mathrm{C} / \mathrm{N}$ yang lebih tinggi akan menyebabkan waktu pengomposan yang lebih lama. Sedangkan Leconte et al. (2009) menyatakan bahwa unsur nitrogen sangat terbatas dalam material kompos yang memiliki rasio $\mathrm{C} / \mathrm{N}$ yang tinggi (lebih besar dari 100). Selain itu, kandungan garam yang masih tersisa serta bahan bioaktif pada rumput laut yang terkandung juga dapat menyebabkan terhambatnya aktifitas bakteri saat proses penguraian bahan organik.

\section{Uji Coba Pupuk terhadap Tanaman}

Pengamatan terhadap tanaman terung dan tomat yang diberi pupuk organik cair rumput laut meliputi: tinggi tanaman, diameter batang, panjang daun, lebar daun, dan jumlah daun (Gambar 2). 

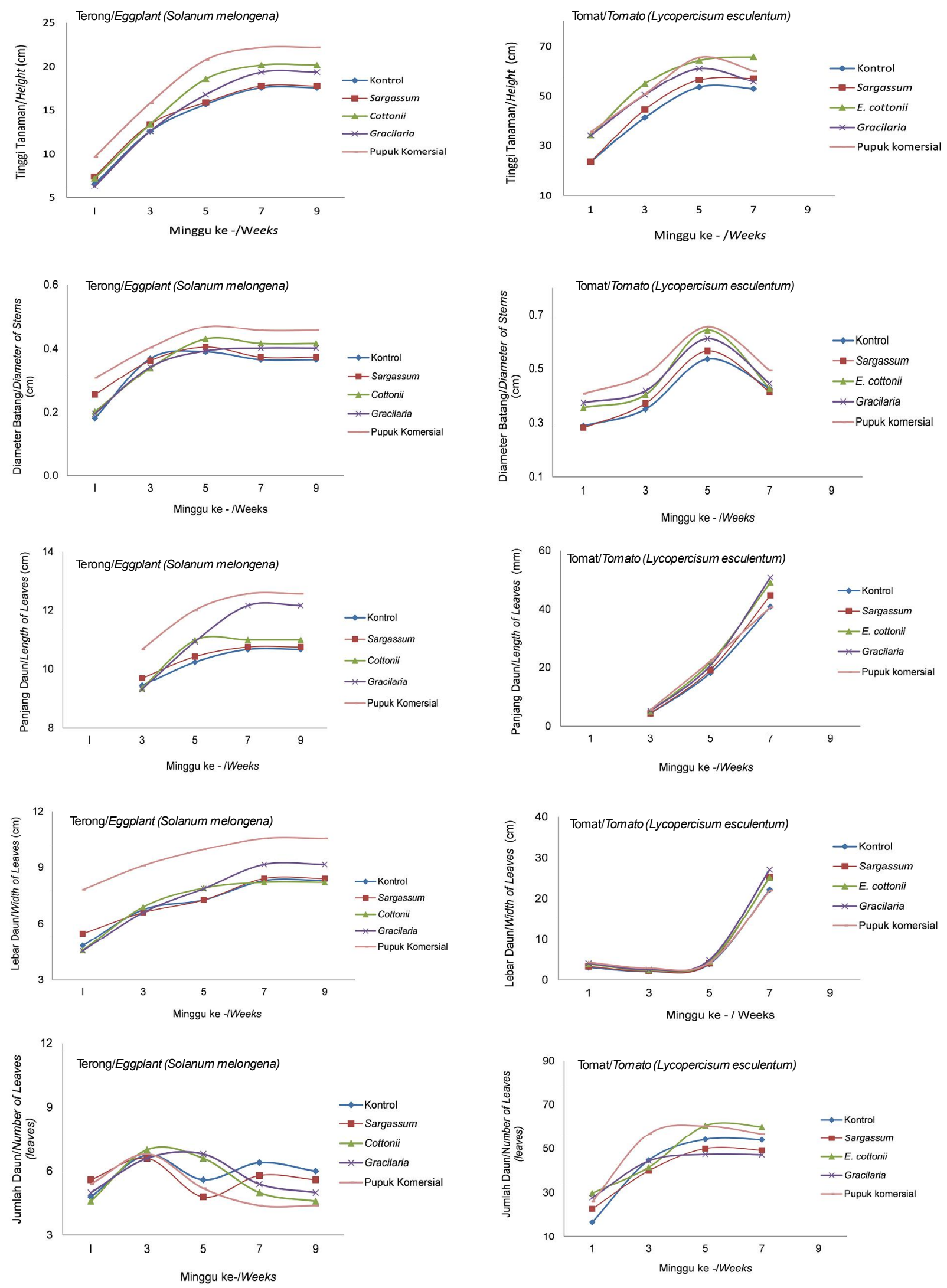

Gambar 2. Pengaruh penyemprotan pupuk organik cair rumput laut terhadap pertumbuhan tanaman terung dan tomat.

Figure 2. Effects of liquid seaweed organic fertilizer foliar spraying on the eggplant and tomato plants. 
Hasil pengamatan menunjukkan bahwa, secara umum aplikasi pupuk cair rumput laut hasil pengomposan dapat meningkatkan pertumbuhan tanaman, baik pada tanaman terung maupun tomat. Tanaman yang diberi pupuk cair dari ketiga jenis rumput laut menunjukkan pertumbuhan yang lebih cepat dibandingkan tanaman kontrol (tanpa pemberian pupuk), terutama pada awal masa pertumbuhan (minggu pertama). Hal serupa dilaporkan oleh Taha et al. (2011), bahwa penyemprotan ekstrak rumput laut memberikan hasil positif yang signifikan terhadap pertumbuhan kecambah tanaman mentimun dibandingkan dengan tanaman kontrol. Sedangkan Featonby \& Van Staden (1983) mendapatkan pertumbuhan tunas dan akar tanaman tomat yang lebih cepat ketika ekstrak rumput laut digunakan ke tanaman, baik dengan penyemprotan (foliar spray) maupun dengan cara dicampurkan dengan tanah. Selain itu, Stephen et al. (1985), juga melaporkan bahwa aplikasi ekstrak cair rumput laut Eucheuma sp. dan Sargassum sp. sebagai bahan tambahan pupuk dapat meningkatkan hasil panen beberapa tanaman komersial penting sebesar $12-36 \%$.

Namun demikian, secara umum dilihat dari kecepatan pertumbuhan tanaman didapatkan bahwa penggunaan pupuk organik rumput laut komersial masih lebih baik dibandingkan dengan ketiga pupuk cair rumput laut hasil pengomposan. Hal ini diduga karena kandungan unsur hara makro maupun mikro yang lebih tinggi dan juga lebih lengkap. Selain itu, penggunaan konsentrasi pupuk cair yang tepat juga memiliki peran penting dalam mendorong pertumbuhan tanaman. Hasil percobaan Srijaya et al. (2010), menunjukkan bahwa seluruh perlakuan konsentrasi ekstrak cair rumput laut memberikan hasil yang positif terhadap pertumbuhan sesawi hitam, namun, pemberian larutan ektrak pada pengenceran 1:100 memberikan hasil yang lebih baik dibandingkan dengan jumlah konsentrasi lainnya. Selanjutnya, Yazied et al. (2012) melaporkan bahwa penyemprotan tanaman menggunakan ekstrak rumput laut pada konsentrasi tinggi $(750 \mathrm{ppm})$ secara signifikan meningkatkan jumlah daun per tanaman, luas daun, berat daun dan batang, dan persentase set buah tanaman buncis dibandingkan dengan kontrol.

Jensen (2004) melaporkan bahwa penyemprotan ekstrak rumput laut dengan kandungan unsur hara mikro (Co, B, Mo, Zn, Cu) maupu makro, serta hormon pemacu tumbuh (auksin, giberelin, dan sitokinin) dapat meningkatkan kemampuan akar tanaman utk pertumbuhan dan penyerapan hara, serta meningkatkan ketebalan batang dan memperkuat pertumbuhan vegetatif dan akar tanaman. Besarnya respon peningkatan pertumbuhan tanaman oleh penggunaan pupuk rumput laut dapat disebabkan oleh:1) efek aditif terhadap peningkatan serapan hara, dan 2) efek dari hormon pemacu tumbuh yang terkandung dalam rumput laut. Hormon pemacu tumbuh dari rumput laut juga berperan meningkatkan penyerapan hara oleh tumbuhan (Crouch \& van Staden, 1993).

\section{KESIMPULAN}

Pupuk organik cair rumput laut yang dihasilkan dengan teknik pengomposan semi-anaerobik memiliki kandungan hormon pemacu tumbuh (auksin, giberelin, dan sitokinin) yang tinggi, dan bahkan lebih tinggi dibandingkan dengan pupuk cair komersial. Kandungan tertinggi dari senyawa tersebut berturutturut didapatkan dari rumput laut yang berasal dari E.cottonii, Gracilaria sp. dan Sargassum sp. namun unsur hara makro $\left(\mathrm{N}, \mathrm{P}_{2} \mathrm{O}_{5}, \mathrm{~K}_{2} \mathrm{O}\right)$ dan mikro $(\mathrm{Mn}, \mathrm{Zn}$, $\mathrm{Fe}, \mathrm{Mo}, \mathrm{Co}$, dan $\mathrm{B}$ ) yang terkandung masih sangat rendah.Selain itu, pupuk cair yang dihasilkan juga masih berbau. Oleh karena itu masih dibutuhkan penambahan bahan lainnya untuk meningkatkan unsur hara pupuk, serta menyempurnakan teknik dan proses pengomposan termasuk parameter pengamatannya hingga didapatkan pupuk organik cair yang telah matang/stabil. Pupuk cair rumput laut ini juga mampu meningkatkan atau mempercepat pertumbuhan tanaman terung dan tomat.

\section{DAFTAR PUSTAKA}

Amilia, Y. (2011). Penggunaan Pupuk Organik Cair untuk Mengurangi Dosis Penggunaan Pupuk Anorganik pada Padi Sawah (Oryza sativa I.). Skripsi Departemen Agronomi dan Hortikultura, Fakultas Pertanian, Institut Pertanian Bogor. 47 pp.

Basmal, J. (2010). Teknologi pembuatan pupuk organik cair kombinasi hidrolisat rumput laut Sargassum sp. dan limbah ikan. Squalen. 5(2): 59-66.

Camargo, J.A. \& Alonso, A. (2006). Ecological dan toxicological effects of inorganic nitrogen polution in aquatic ecosystems: A global assessment. Environmental International. 32: 831-849.

Chang, J.I. \& Hsu, T.E. (2008). Effects of compositions on food waste composting. Bioresource Technology 99: 8068-8074.

Cocozza, C., Parente, A., Zaccone, C., Mininni, C., Santamaria, P. \& Miano, T. (2011). Comparative management of offshore posidonia residues: composting vs. energy recovery. Waste Management (Oxford) 31: 78-84.

Crouch, I.J. \& Van Staden, J. (1993). Evidence for the presence of plant growth regulators in commercial seaweed products. Plant Growth Regulation 13: 2129.

Dewanto , F.G., Londok, J.J.M.R., Tuturoongdan, R.A.V., \& Kaunang, W.B. (2013). Pengaruh pemupukan 
anorganik dan organik terhadap produksi tanaman jagung sebagai sumber pakan. Jurnal Zootek. 32(5) $1-8$.

Dhargalkar, V.K. \& Pereira, N. (2005). Seaweed: promising plant of the millennium. Science and Culture. 71: 60-66.

Featonby-Smith, B.C. \& Van Staden, J. (1983). The effect of seaweed concentrate on the growth of tomato plants in nematode-infested soil. Scientia Horticulturae. 2: 137-146.

Fornes, F., Sanchez, P.M., \& Guadiola, J.L. (2002). Effect of a seaweed extract on the productivity of 'de Nules' Clementine mdanarin navelina orange. Botanica Marina. 45: 486-489.

Gardner, F.P., Pearce, R.B., \& Mitchell, R.L. (1991). Fisiologi Tanaman Budidaya. Cetakan Pertama. Penerjemah Susilo, H., Universitas Indonesia Press, Jakarta.

Han, L.J. (2006). The auxin concentration in sixteen Chinese marine algae. Chinese Journal of Oceanology and Limnology 24 (3): 329-332.

Han, W., Clarke, W., dan Pratt, S. (2014). Composting of waste algae: A review. Waste Management. p. 1-8. http://dx.doi.org/10.1016/j.wasman.2014.01.019. Diakses pada tanggal 20 Agustus 2014

Haslam, S.F.I. \& Hopkins, D.W. (1996). Physical dan biological effects of kelp (seaweed) added to soil. Applied Soil Ecology. 3: 257-261.

Indriani, Y.H. (2004). Membuat Kompos Secara Kilat. Penebar Swadaya, Jakarta.

Jensen, E. (2004). Seaweed-fact or fancy: From the organic broad caster, Published by Moses the Midwest Organic dan Sustainable Education, From the Broad Caster. 12(3): 164-170.

Jensen, A. (1993). Present dan future needs for alga dan algal products. Hydrobilogia. 261: 15-21.

Jimenez-Escrig, A. \& Goni, C.I. (1999). Nutritional evaluation and physio logical effects of edible seaweeds. Archivos Latinoamericanos de Nutrition 49: 114-120.

Leconte, M.C., Mazzarino, M.J., Satti, P., Iglesias, M.C., \& Laos, F. (2009). Co-composting rice hulls and/or sawdust with poultry manure in NE Argentina. Waste Management. (Oxford)29: 2446-2453.

Linskens, H.F. \& Jackson, J.F. (1987). High Performance Liquid Chromatography in Plant Sciences. SpringerVerlag. London. $241 \mathrm{p}$.

Mooney, P.A. \& Van Staden, J. (1984). Seasonal Changes and in the Level of endogeneous Cytokinin in Sargassum heterophylum (Phaeophyceae). Bot. Mar. 27: 437-442.
Padhi, S.B. \& Swain, P.K. (2006). Effective Role of Microorganism dan Seaweed as Biofertilizer in Organic Farming for a Sustainable Environment. http://wgbis.ces.iisc.rnet.in/energy/lake2006/ programme/programme/proceedings / fullpaper_pdfs/Sailabala\%20Padhi.pdf. Diakses pada tanggal 13 Oktober 2008.

Permentan. (2011). Peraturan Menteri Pertanian No.70/ Permentan/SR.140/10/2011. Pupuk organik, pupuk hayati, dan pembenah tanah. $16 \mathrm{pp}$.

Prithiviraj, B. (2009). Seaweed extracts as biostimulants of plant growth dan development. Plant Growth Regulation. 28: 386-399.

Sedayu, B.B., Basmal, J. \& Utomo, B.S.B. (2013). Identifikasi hormon pemacu tumbuh ekstrak cairan (sap) Eucheuma cottonii. Jurnal Pascapanen dan Bioteknologi Kelautan dan Perikanan. 8(1): 1-8.

Sivasankari, S., Venkatesalu, V., Anantharaj, M., \& Chdanrasekaran, M. (2006). Bioresource Technology 97: 1745-1751.

Srijaya, T.C., Pradeep, P.J., \& Chatterji, A. (2010). Effect of seaweeed extract as an organic fertilizer on the growth enhancement of black mustard plant. Journal of Coastal Environment. 1(2): 137-150.

Stephen, A.B., John, K.M.T., Palnia, L.M.S., \& Lethama, D.S. (1985). Detection of cytokinins in a seaweed extract. Phytochemistry. 24(11): 2611-2614.

Taha, Z.S., Smira, T.A., \& Sanaa, M.S.R. (2011). Effect of bread yeast application dan seaweed extract on cucumber (Cucumis sativus L.) plant growth, yield dan fruit quality. Mesopotamia Journal of Agriculture 39: 26-34.

Udiyani, P.M. \& Setiawan, M.B. (2003). Kajian terhadap Pencemaran Lingkungan di Daerah Pertanian Berdasarkan Data Radioaktivitas Alam. Prosiding pada Seminar Tahunan Pengawasan Pemanfaatan Tenaga Nuklir, Jakarta, 11 Desember 2003. p. 172182.

Win, L.L. \& Saing, K.M. (2008). Effectiveness of Myanmar brown seaweed (Sargassumspp.) extract as organic fertilizer in pot trial of rice. GMSARN International Conference on Sustainable Development: Issues dan Prospects for the GMS. $4 \mathrm{p}$.

Wu, T.W. \& Lin, C.H. (2000). Analysis of cytokinin activity in commercial aqueous seaweed extract. Gartenbauwissenschaft. 65(4): 170-173.

Yazied-El, A., Gizawy-El. A., A.M. Ragab, M.I., \& Hamed, E.S. (2012). Effect of seaweed extract dan compost treatments on growth, yield dan quality of snap bean. Journal of American Science 8: 1-20. 